\title{
ELEMENTS OF DAKWAH AND LOCAL WISDOM OF THE BAJAUS IN THE ANTHOLOGY OF POETRY ILTIZAM
}

\section{(Unsur Dakwah dan Kearifan Tempatan Orang Bajau dalam Kumpulan Puisi Iltizam)}

Rabiatul Adawiah binti Ab. Samad

rabiatul_adawiah@gapps.kptm.edu.my

Kolej Poly-Tech Mara Semporna

Low Kok On

lowkonon@ums.edu.my

Unit Penyelidikan Warisan Borneo, Universiti Malaysia Sabah

Hashim Awang

Fakulti Kemanusiaan, Seni dan Warisan, Universiti Malaysia Sabah, Malaysia.

\begin{abstract}
Iltizam is an anthology of poetry produced by Zubir Osman in 2015, in his effort to deliver poems with the element of dakwah or propagation of Islam and to showcase local wisdom, in particular that of the Bajau ethnic group in Sabah. This article focuses on 59 selected poems in the anthology that contain the elements of dakwah and local wisdom. The discussion in this article focuses on the dakwah element which is portrayed in and linked to the culture, way of life and nature of the Bajau people. The dakwah approach is the principle contained in the Malay methodology theory which has been used to explore the dakwah aspect while the utilitarian approach is used to examine local wisdom characteristics which reflect the heritage and identity of the Bajaus
\end{abstract}


in Sabah. This analysis of Iltizam selected poems finds that the poems with the Islamic element not only involve the writer's imaginative capability and creativity but they also become effective vehicles for dissemination to the public. It can be concluded that Iltizam presents the dakwah element and local wisdom of the Bajau people through the poetic verses as a manifestation of the world view and beliefs of its society.

Keywords: Bajau ethnic group, Iltizam, poetry, local wisdom, dakwah approach, utilitarian approach, Malay methodology theory

\begin{abstract}
Abstrak
Iltizam ialah sebuah antologi puisi karya Zubir Osman yang dihasilkan pada tahun 2015 dalam usahanya untuk menyampaikan puisi-puisi berunsurkan dakwah dan pemaparan kearifan tempatan, khususnya dalam kalangan suku kaum Bajau di Sabah. Makalah ini memberikan tumpuan terhadap 59 buah puisi pilihan dalam antologi puisi Iltizam (2015), yang mengandungi unsur dakwah dan kearifan tempatan. Perbincangan makalah ini secara langsung memberikan tumpuan terhadap unsur dakwah yang dipaparkan dan dikaitkan dengan budaya, cara hidup dan keperibadian suku kaum Bajau. Pendekatan Dakwah merupakan prinsip yang terkandung dalam teori pengkaedahan Melayu dipilih untuk menelusuri aspek dakwah manakala pendekatan gunaan diguna pakai untuk meneliti unsur-unsur kearifan tempatan yang memperlihatkan warisan dan identiti masyarakat Bajau di Sabah. Analisis terhadap puisi pilihan Iltizam (2015) mendapati bahawa puisi berunsurkan Islam bukan hanya melibatkan daya imaginasi dan kreativiti pengarang, malah merupakan wadah penyampai yang berkesan kepada masyarakat. Kesimpulannya, Iltizam (2015) mengetengahkan unsur dakwah dan kearifan tempatan orang Bajau melalui bait-bait puisi sebagai manifestasi pandangan hidup dan kepercayaan masyarakat Bajau sendiri.
\end{abstract}

Kata kunci: Suku kaum Bajau, Iltizam, puisi, kearifan tempatan, pendekatan gunaan, pendekatan dakwah, teori pengkaedahan Melayu

\title{
INTRODUCTION
}

The 1980's saw the development of Malay literature containing Islamic elements in a variety of genres such as the novel, short story and poetry. Poetry is a branch of modern Malay literature which represents a poet's creativity. Poetry containing Islamic elements is viewed as a significant development in the attempt to provide a positive impact on universal humanity. Local wisdom refers to the knowledge acquired in a community from the experiences 
of its members as well as its collective knowledge (Kamonthip, 2007:1). Local wisdom is also linked to traditional elements and the practices of the region's society that encompass wisdom, knowledge and teachings such as laws, safety, life, human resource and beliefs (Nyoman Utari, 2008:4).

This study employs the dakwah and utilitarian approaches in the effort to explore the dakwah aspect and the Bajau society's local wisdom based on 59 selected poems in Iltizam (2015). The Bajaus are one of the biggest ethnic groups in Sabah (Yap, 1993:xi). The Bajaus are classified into two groups, namely the Bajaus of the West Coast who are mostly farmers and the Bajau group in the East Coast of Sabah who are well known as fishermen. The early history of the Bajau society comes in various versions, for example through observations by western orientalists such as Frost who stated that he discovered Bajau fishermen all along the east of Borneo Island and it is believed that the fishermen were originally from Johore. (Warren, 1971, p. 65). Local researchers such as Yap (1993, p. 13), classified the Sea Bajaus and the Land Bajaus based on their physical characteristics, the language, way of life as well as customs although both are called Bajau. The sea Bajaus live in areas such as Semporna, Kunak, Lahad Datu and Sandakan. The land Bajaus live in places like Kota Belud and Tuaran. The Sea Bajaus are very close to nature. This closeness influences the society's local wisdom which then forges its own unique identity. The influence of Islam in Nusantara also had an impact on the Bajau community which practiced animism before converting to the Islamic religion. Iltizam (Commitment) (2015) is the poet's inspiration to create awareness about Islamic dakwah while introducing the identity and culture of the Bajaus as a whole.

\section{HASHIM'S MALAY METHODOLOGY THEORY (1989)}

Hashim (1989:60) introduced the Malay methodology theory out of his desire to interpret and delve into literary works that exist in Malay culture by employing a suitable theory. Hashim (1989) felt that it was time Malay literary works that contain Islamic elements be dissected based on new theories that can bring a positive impact to society and at the same time reduce dependence on western theories which are less relevant in the analysis of local works. This theory is based on Malay views related to religion and Malay philosophy of life. Three core aspects of welfare, obedience and manners and the whole way of life is founded on Islamic belief. 
The Malay methodology theory is divided into two approaches, that is, the natural approach and the religious approach. The natural approach is based on factors like culture, life and the Islamic religion which is the pillar of the Malay society. Nature is the closest ally of mankind and carries a huge meaning in the lives of the Malays, and is often used as a guide and lesson in proverbs or poems which we use until today. The natural approach is divided into smaller sections, that is, the utilitarian approach, the moral approach and the interpretative approach. The utilitarian approach means everything that is created by Allah SWT has its own role and importance. Similarly, the literary work produced with Allah's permission actually exists for a reason, has an underlying wisdom and its own function. This approach involves intrinsic and extrinsic elements that include the background of its creation, the society, its readers, the author and his ideology. This literary work is viewed as the expression of the writer's feelings about a certain subject that he wants to convey to his society.

This approach is found to be relevant in examining the Iltizam anthology (2015) since the Bajau society's life and background are similar to Malay culture. This approach can be used directly to analyse Zubir's poems as they are similar to the Sea Bajau's local wisdom. The religious approach is wholly based on the concept of faith and the Qur'an and hadith (the Traditions). This approach is divided into three supporting theories, that is, the dakwah approach, the societal approach and the artistic approach. Dakwah according to Asmuni (1983:19) means any activity that is in the nature of an invocation, invitation or call to the people to have faith and believe in Allah SWT in line with the Islamic creed, laws and morals. Othman (2000) defines dakwah based on the word masdar from the verb $d a^{\prime} a-y a d^{\prime} u$ that means invoke, appeal or invite. The word dakwah is often used with the word ilmu (knowledge) and the word Islam, hence the phrases ilmu dakwah and dakwah Islam or al-da'wah al-Islamiyah. Hashim Awang's Malay Methodology Theory (1989) as a whole is summarised in Figure 1

Based on Figure 1, it is clear that the dakwah approach and the applied approach are the two principles contained in Hashim Awang's Malay Methodology Theory (1989). In this article, the dakwah approach that is categorized under religious approach has been selected to explore the dakwah aspect found in Iltizam's selected poems (2015). The utilitarian approach, classified under natural approach is used to examine the local wisdom that showcases the heritage and identity of the Bajau society in Sabah in Iltizam's selected poems. 


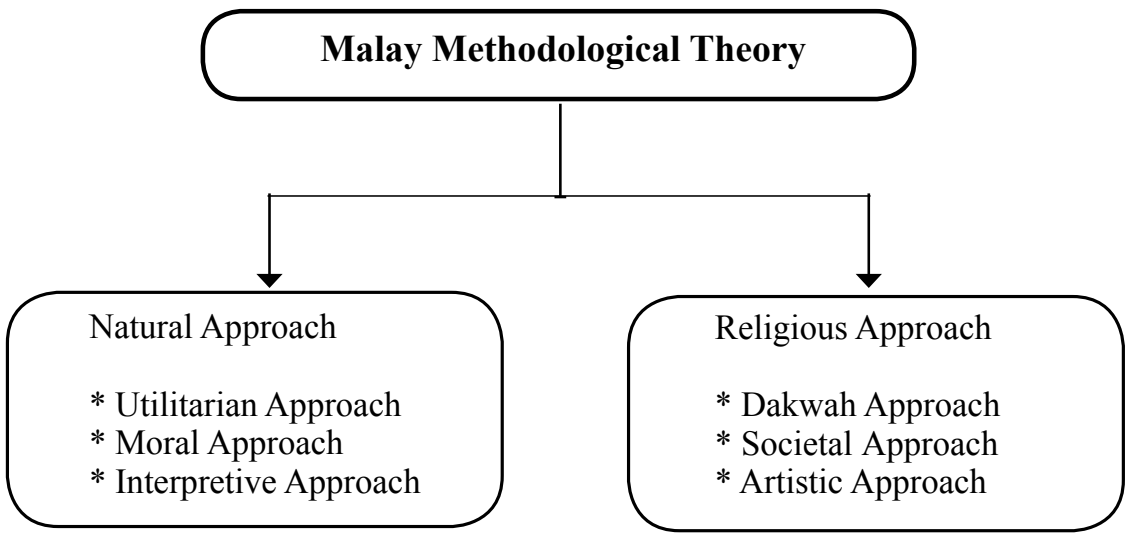

Figure 1 Malay Methodological Theory Hashim Awang (1989).

\section{RESEARCH MATERIAL}

Iltizam, the anthology of poems by Zubir, published in 2015 by ITBM (Institute of Translation and Books Malaysia), contains one hundred and fourteen poems that cover various themes such as society, nature, divinity, regret for one's wrongdoing, and acceptance of one's fate. The poems in this anthology are the expression of the writer's feelings in his love for Allah and an attempt to bring the public to reflect on Allah's majesty and greatness. The writer tries to present a unique depiction of the life of his people at the same time emphasizing the Islamic religion as its main foundation. Zubir (2015) is seen as showing the culture, heritage, identity and way of life of his people in a better light so that the reader will better understand the way of life of the Bajaus.

\section{THE ELEMENT OF DAKWAH AND LOCAL WISDOM}

The process of life experienced by the poet as a member of the Bajau community, is manifested through the verses of his poems. Based on the dakwah approach and utilitarian approach, poetry is seen as representing the life experiences, culture, art and heritage of its writer. In fact, the Iltizam anthology is the expression of ideas and experiences of its writer who has long been involved in the poetry genre, which should reflect his people's way of life in the future. The Bajaus have begun to learn about literature and the expression of ideas in a more creative form. This level is reached 
after a very tough life process, being exposed to various obstacles and challenges through the generations until it became difficult to maintain the nation's identity. Finally, the poet came forward as a member of the Bajau community who tries to express his feelings and inner turmoil through the portrayals in the poems he writes.

"As for the poets, those who err follow them. Have you not seen how they stray in every valley. And how they say which they themselves do not do. Except for those poets who believe and remember Allah much until they succeed. And those who stray will know where they will be sent.

(Surah as-Syuara'ah 26: 224-227)

Dakwah in literature refers to the ability of a piece of work to be a vehicle and medium of dissemination to create awareness about the truth and good in Islam. Literary works such as poetry should be more inclined to include themes that deal with social issues in order to provide lessons and guidelines to the public. The poet has the responsibility of creating awareness within society as to Allah's greatness, to redeem oneself of sins, about faith, the creed and other topics in order to encourage people to remember Allah throughout their lives. Allah SWT has stated in the Qur'an about Muslim poets who should act differently from those who stray through the Surah assyuara 'ah. Zubir (2015) has put forth the element of dakwah in all his poems in an effort to be one of the Islamic poets who advocate good and the truth according to Islamic rules and laws. This is reflected in the following stanza:

Berterima kasihlah pada alam dan Penciptanya

selama iradat bersamamu

kuduskan hasrat milik tuhan itu

akan kutemu juga jalan

dan berpeganglah pada tali-nya.

(Iltizam, 2015, p. 18)

[Be grateful to the world and its Creator

while together with you

may the wishes be pure unto God

I will discover the path

and hold on to His rope] 
Zubir (2015, p. 18), through his poem Lagu Perahu Dikayuh (Song of boat being rowed) tries to inculcate patience and gratitude to Allah, the Creator of the world. Human beings should be subservient, obedient and accepting as well as believe in the fate destined to us by Him. As long as mankind follow the straight path, Allah will bless the journey of his creations.

Kudrat tak seindah takdir

benang pengikat tinggal iman cuma

dengan jarum ikhtiar

digotong sebakul penuh sutera tawakkal

(Iltizam, 2015, p. 2)

[Strength is not as beautiful as destiny

the only tie that binds is faith

injected with effort

and surrendering one's fate to the Almighty]

The poem Kudrat (Strength) (Iltizam, 2015, p. 1) is similar to Lagu Perahu Dikayuh (Iltizam, 2015, p. 18) in that it deals with the virtues of patience and acceptance in overcoming life's challenges. The poet's verses are in line with the dakwah approach which encourage the function of literary works as a medium for dissemination of the dos and don'ts in religion to society.

This element is also shown in several other poems such as Bertelagah (Fighting) (Iltizam, 2015, p. 15) in the following stanza:

\section{Mari menadah tangan memohon hikmah}

Saling penuh sedar diri bertongkat keinsafan

Hidup terlalu singkat

[Come, open your palms and pray

Together with awareness and supported by regrets

Life is too short]

The poet does his utmost to create awareness among the people about our needs as servants of God and who are accepting of the many trials and challenges in life. Only Allah SWT knows our fate and destiny.

Demi Tuhan yang memegang nyawaku

tiada kejadian lebih agung

selain penciptaan alam semester 
Yang bermula dari DUKKHAN

konstant mengembang

mengempar ke seluruh penjuru

mencipta dalam enam masa

dan Dia bersemayam di atas Arasy

(Iltizam, 2015, p. 7)

[By Allah, who holds my life in His hands

no better creation except that of the whole universe

starting with DUKKHAN

constantly developing

booming to all corners

creating in six times

and $\mathrm{He}$ is enthroned on Arasy]

The above excerpt is known as Ittakullah poetry which embodies the concept of takwa (to fear or obey Allah). The writer tries to make people aware of the greatness and majesty of the Creator. Allah SWT has the power over our lives, creating every single thing on earth. Another stanza touches on Allah's attributes in detail in the poetic verses. The writer reflects on the oneness of Allah, neither having a child or being one, never sleeps or naps, arranging every natural occurence flawlessly. Man who is created as His vicegerent on earth should learn from observing Allah's power. The writer succeeds in showing his love for Allah through the description of Allah's attributes of oneness and almighty.

"O mankind, worship your Lord who created you and those before you so that you become the righteous".

(Surah al-Baqarah 2:21)

Allah urges mankind to always worship Him, God who created mankind. Surah al-Baqarah verse 21 explains that as Muslims, they are enjoined to obey everything that has been instructed by Him through the Qur'an and hadith. The writer through his poems Iradatmu (Your will) and Pulang Aku Pada-Mu (I return to You) appeal to mankind to seek Allah's acceptance and guidance to achieve happiness in this world and the hereafter. The elements of dakwah are clearly seen in these verses that revolve around themes such as repentance, obedience to Allah and the oneness of Allah. Observe the following verse: 
Berkayuh perahu disubuh hari

menguak rezeki mengutip mutiara hidup

riak ombak puput bayu bukan ujian semu

semua datang membawa dulang pengertian

meminang ketabahan diri

mengahwini pancaroba

meniduri cinta derita yang telanjang

tanpa selimut iman

(Iltizam, 2015, p. 18)

[Rowing the boat in early morn

To earn a living gathering mussels

The waves swayed by the breeze are not the test of a storm

All come bringing lessons

To court courage

To overcome challenges

Sleeping with naked suffering

Without the cover of faith]

The use of the word "perahu" (boat) above, in the poem Lagu Perahu Dikayuh (Iltizam, 2015, p. 18) is an example of highlighting the identity of the Bajau community that through generations depended on the boat in their lives. The boat is a symbol of the lives of the Bajaus, especially those living in the east coast of Sabah who are reputed to be skilled fishermen and divers. The boat is seen as the main source of earning a living from the sea. This shows how close the writer is with the lives of the Bajau people and it is the core of his identity and shines through the beautiful rendering of his poem. Perahu, Lepa, Boggok, Bayanan and Sappit are the means of transportation at sea that are synonymous with the lives of the Bajau society. This is manifested by the writer in his poems as an embodiment of the true seaman. The heritage passed on from generation to generation which will never be forgotten by the Bajaus. Typically, the Bajaus not only use the boat as a source of earning a living but also in the traditional past the boat was also the house or place to live for the Bajaus. This poem is seen to be in line with the utilitarian approach that involves both intrinsic and extrinsic elements covering the background of its creation, the society and the writer, all of which enable him to express his feelings about his people which he wants to introduce to the readers. 
Kalau perahu sebesar sabut cuma

jangan takut meredah gelora

kalau dayung buatan kayu seraya hanya

dayung saja sekuat tenaga

siapa tahu dalam dayung hilang arah

ketemu pulau tertanam sejuta harta

berani mengorak berani bersorak

tabah mengira jarak bersama awan mengarak

(Iltizam, 2015, p. 18)

[If the boat is only as big as the husk

do not fear treading the waves

if the oar is only of a wooden plank

just row with all your might

who knows in the oar losing direction

one discovers an island of treasures

the brave one will end triumphant

bravely counting the distance together with the moving clouds]

Zubir (Iltizam, 2015, p. 18) in the third stanza writes this poetic expression: "if the boat is only as big as the husk, do not fear treading the waves" as the beginning lines of the third stanza. Poetic expressions, symbolism and pantun are valuable heritage and become the symbol of a society's identity, a society which values politeness in speech. The Bajaus also value manners and polite behaviour especially in speech and interactions with the society. Poetic and grammatical phrases are the vehicle for conveying what is in the mind and thinking of the society which then is expressed through subtle and refined ways. The writer employs this element to express his feelings in the sincere struggle that his people gain strength and awareness to reach for success. Although strength is limited, one must continue in one's efforts to gain the objectives in life. Such advice are in accordance with Islamic values which encourage its people to work hard to change their lives for the better, in line with the word of Allah in Surah $a r-R a$ ' $d$ verse 11, that is "Allah will not change the fate of a nation until they change what is in themselves".

Local wisdom is clearly one of the important aspects in his effort to pen the finest poems for his readers. The local wisdom which he writes about include the line of thinking, life philosophy and the principles upheld by the Bajaus. The utilitarian approach emphasises that everything created has its own role. Life experiences finally become a useful message to be passed on to the readers. 
Biar mati anak jangan mati adat

jika mati adat hilang madu umat

kerana hidup bersendi muafakat

diri mandiri sesuai syariat

barulah tercapai makrifat

hingga tersingkap hijab

dan tampaklah hakikat

Better to lose a child than lose one customs

To lose one's customs means the end of sweet fraternity

Because consensus supports life

The laws suit oneself

Then will makrifat be achieved

Even the veil is lifted

And truth is revealed

The poem, "Hakikat" (Iltizam, 2015, p. 64) through the expression, "better to lose a child than lose one's customs" is symbolic of the Malay world that colours their lives. The Bajaus acknowledge being under the administration of Malaysia. Therefore, the elements contained in Malay history find a place in their hearts too. Custom is the pulse and pillar of the community, this is what the writer is trying to convey via his poem. The Bajau society is known for bravery and faithfulness to custom and promises. Good seamen are those who possess upright personalities with high moral values. This philosophy of life is also required in Islam in order to produce human beings with noble characteristics as in the following:

Biar senget jangan rebah

biar tunduk namun tetap menanduk

biar diam namun akal menjelajah

biar di belakang namun idea sentiasa dihadapan

biar derita seketika namun bahagia selamanya

biar terasing namun dekat pada-Nya

biar miskin harta namun kaya gelora batin rasa

biar melangkah namun hasrat melayang saujana

biar menyimpang namun terbilang

(Iltizam, 2015, p. 64)

[Let us bend but not collapse

let us bow but still attack 
let us be silent but the brain soars

let us be at the back but the idea is always in front

let us suffer a while but happy forever

let us be separate but close to Him

let us be poor but rich in heart and soul

let us take steps but intention goes far

let us deviate but be counted]

The phrase "let us bow but still attack" has an underlying meaning. The poet wants the Bajaus to be humble but still be able to defend their principles. These words strike a chord with the Bajau community that is considered to have sacred and spirited values. Let us be the spine as long as we have fruitful and excellent ideas. The difficulties in life faced today does not mean there is no scope or room for success. The Bajau's philosophy of life emphasizes on toughness and courage as well as to always remember one's identity and the nation's that is constantly influencing their lives. This concept is also in line with Islamic values that is to be moderate in all things. Every trial and challenge should be faced by every human being in order to become a devoted servant of Allah.

Dakwah elements are synonynmous with the writer. Each poem he wrote in Iltizam anthology such as "Kudrat", "Kucari Jalan", "Jalan Tak Berhujung", "Salawat atas Nabi", "Tawakkal", "Mati Sebelum Ajal", "Hakikat", "Iltizam", "Tuhan", "Lelaki Sejati”, "Aku, Tuhan dan Hidup", Sesudah Kutahu, "Tuhan Jangan Tinggak Daku”, "Ittakullah”, "Menanti Dijemput Waktu”, "Mati”, "Trigonometri Cinta", "Alam", "Pandoga Salah Tingkah" and many others by Zubir (2015) contain advice and dakwah to steer one towards the truth in accordance with the writer's belief in the Islamic religion.

The intrinsic and extrinsic elements such as culture, the arts and personality of the writer are some of the factors in the writing of poetry that has a cathartic impact on the public.

The writer clearly makes his poetry as a vehicle in the struggle to call people to the right path. The poem, "Pagi Datang Lagi" (Morning Comes Again) (Iltizam, 2015, p. 22) depicts the attributes of the chosen prophets such as the wisdom of Moses, the courage of the Prophet Sulaiman, the manners of the Prophet Ismail, the firmness of Prophet Abraham and the greatness of Prophet Muhammad. The stories of these prophets certainly contain many lessons and guidance in life. Abraham who was very devoted to Allah obeyed Him when instructed to slaughter his son, Ismail as decreed by Allah. The sacrifice that he made was solely for religious sake. This is the 
story on which Aidil Adha is celebrated in the Muslim history. The poem, "Salawat atas Nabi" (Iltizam, 2015, p. 23) also stresses on remembrance of the Prophet Muhammad SAW in the verses describing the birth of the prophet. This poem presents the prophet's genealogy and his unworldly characteristics. He is known for his forgiving nature, his polite behaviour, and that he possesed only two garments. For him religion was his life. This story is very moving and the writer succeeds in portraying the life of the prophet in a fine and respectful manner. Such moderation should be used as an example by the society which is bent on chasing worldly goods to the extent of forgetting the hereafter. This theme is also present in the poem, "Aku Ingin Jadi Nabi" (I want to be a prophet) (Iltizam, 2015, p. 34) where again the writer portrays the lives of Islamic figures such as Uwais al-Qarni, Hasan al-Basri, Al-Ghazali, Rabiatul Adawiyah and Abu Yazid al-Bistami to provide good examples to society.

The poem, "Kucari Jalan" (I am looking for the way) (Iltizam, 2015, p. 11) depicts the struggle of a man who is seeking the straight path. Mankind has been made God's vicegerents on earth who are devoted to Allah and take care of his creations. He has instructed mankind to serve Him always. The relationship between man and Allah is vertical, that is hablumminallah and the relationship between man and man is hablumminanas. Therefore, mankind is urged to remember Allah at all times and seek the path which will bring him closer to Him.

Allah is the Creator of every single thing on earth and in the hereafter. Allah SWT has the attributes of greatness and majesty. Allah has created the sky, the earth, the sun, the moon and everything that can be discerned by our senses or otherwise. Allah's greatness and majesty can be felt when humans reflect on the creation of the huge expanse of the earth and all that take place in this world. The natural world such as the waves, heaving seas, the wind and so on are part of the beautiful elements of his poetry that depict the closeness of the Bajaus with the natural environment. The Bajaus are seafarers who are not afraid to interact with nature. The waves are the symbol of trials and tribulations in life. The natural world represents the relationship between tradtional Bajaus and their Creator.

\footnotetext{
"And of his signs is the creation of the heavens and the earth and the diversity of your tongues and colours. For in this there are messages indeed for all who are possessed with innate knowledge".
}

(Surah ar-Rum 30:22) 
Surah ar-Rum states that Allah has created every thing which has its own role. The sky and the earth which were created always play their individual roles. The truth is, every sign in this world has proven that Islam is a complete religion and underlines the way of life of the society as a whole.

Although life does not promise success the poet attempts to inject hope especially within the Bajau society to continue to be brave in moving forward to find a better life in the midst of their life journeys. Only those who want to know further will look at each test and challenge as something that motivates in order to live a better life:

Si pencari kebenaran menaakul

Maha melihat segala tindakan kitaam

Si dungu mengangkut karung bernafsu

Si lalai memperjudikan emas waktu

Sedang tuhan tidak pernah tidur

(Iltizam, 2015, p. 11)

[The seeker of truth reasons

The Almighty sees all our actions

the dumb gathers the bag of nafs

the idle wastes the precious time

whereas God never sleeps]

The poet emphasises the message that every suffering and bitterness in life should become a lesson and guide in our everyday lives. The world is our real teacher in order for us to become more advanced and be able to live with the times. The role of the world which is highly important instil a deep feeling of love in us towards God the Creator because we are given the chance to experience the pleasures of being human. This poem clearly depicts two situations that will occur if a human being allows himself to drift without looking for a way to return. Those who make an effort to seek the truth, although falling along the way at times, is a human being who is full of courage and love. A pure soul should be able to balance reason and become a better human being.

The poem "Alam" (Nature) (Iltizam, 2015, p. 32) also portrays the relationship between the world and its Creator. The writer tries to portray by nature symbols that every human being should think wisely in living his life. This theme is also presented in the poem "Gelap" (Dark) (Iltizam, 2015, p. 43) that depicts the world at night. The gloom and the pitch darkness that 
clamps the soul. "Menjerat Mentari" (Trap the Sun) (Iltizam, 2015, p. 194) and "Bunga Ilalang" (Ilalang flower) (Iltizam, 2015, p. 103) also revolve around nature, containing various stories of sorrow and suffering in a society. "Datang Sudah Suria Pagi" (The Morning Sun Has Risen) (Iltizam, 2015, p. 174) and "Cahayaku" (My Light) (Iltizam, 2015, p. 113) also use the natural backdrop in its symbolism in the writer's dakwah regarding the importance of nature and its relationship with man. The poem "Moga Bukan Terakhir Dariku" (Hoping it's not the Last from Me) (Iltizam, 2015, p. 172) presents nature elements such as the rainbow, light, stars, night and day. It is clear that the poet uses nature elements in almost ten of his poems in Iltizam anthology of poetry (2015).

The poet writes about his hopes and dreams in the poems "Aku Punya Satu Impian" (I have a Dream) (Iltizam, 2015, p. 45) and "Ratib Orang Kesurupan" (Recitation of One Possesed) (Iltizam, 2015, p. 119) of being able to witness peace and prosperity for human kind. His dream is to see love and living together without being burdened with evil and ignorance. The poems reflect the hopes he keeps in his heart that society can live without an iota of prejudice. With regard to the life of the Bajau society, sometimes there is enmity in their lives which lead to fights that can threaten peace and harmony among the people. It is this hope which he tries to push forward so that society, especially the Bajau society understand their responsibility and roles as members of a society. Peace and prosperity are the things people hunger for in this world. "Dunia Papan Catur" (The World as a Chessboard) (Iltizam, 2015, p. 121) is about a society that constantly find fault without practicing tolerance and understanding which eventually would destroy itself. The writer tries to depict the consequences of such a society that find fault among themselves without any attempt to improve their lives as one big unit. The poem, "Puisi Tidak Menyerah" (Poetry Does Not Surrender) (Iltizam, 2015, p. 125) on the other hand pictures life in a society that always works towards finding purity in life and meeting the Creator. Social issues such as these can leave a beneficial impact on the readers so that they constantly strive for peace and tolerance in life. This is what Islam stresses on because mankind is created to help each other and cooperate to achieve progress and excellence.

The poem "Menanti Dijemput Waktu" (Waiting for the Appointed Time) (Iltizam, 2015, p. 99) is seen as a portrayal in detail of the lives of traditional Bajaus which have been practiced from generation to generation until today. Food such as boiled cassava is the main staple of the Bajaus 
and it is the symbol of their identity. Boiled cassava is of sentimental value for the whole Bajau community. Usually this is their breakfast, and it is affordable enough to feed all members of the family even if they are poor. The poet tries to present the reality of life of these seafarers who are destitute. Cassava is considered a staple food as rice is. The daily life of the Bajaus is felt to be incomplete without a variety of seafood. Prawns, fish and dried squid in poetry are symbols of the daily life of these fishermen. These fishermen struggle against the waves to look for food and earn a living for the family. The depiction of their lives by the poet leave a deep impression on the readers. The Bajaus who are living in poverty do not even possess lamps, let alone air conditioners. However, Islam which underlie their life philosophy enable them them to be grateful inspite of their poverty and difficult lives. As long as they are physically able, they will go on earning their living. The writer emphasizes the virtues of acceptance of fate and regret for one's wrongdoing in the poem with the deep undertanding that whatever trial God gives is within one's capacity to bear. The Bajaus consider that this is what it means to be accepting (reda) until the time one meets the Maker. Zubir's poems (2015) are in line with the utilitarian approach, that is they are supported by the notion that part of life experiences have an underlying meaning.

The writer in trying to use poetry as a medium for dakwah has not forgotten to talk about the issues of destiny and death as a particular reminder to society. Destiny and death are things that are outside the knowledge of human beings. The poem, "Inna Lillahi Wa Inna Ilaihi Raji'un" (Iltizam, 2015:84) urge mankind to do as much good deeds for the final reckoning in the hereafter because death can come at any time. The poem "Mati" (Death) (Iltizam, 2015:130) also represents the journey of a person who is nearing death. Only Allah knows the time when death comes. Therefore mankind is encouraged to perform many good deeds and to do good in this world for the final reckoning. The poem "Pulang Aku Kepada-Mu" (I Return to You)(Iltizam, 2015:105) revolves around the same theme of urging people to the right path so that the last moments of life will be easier. The poem "Puisi Mu I" (Your Poem I) (Iltizam, 2015, p. 51) and "Puisi Mu II" (Your Poem II) (Iltizam, 2015, p. 177) are also of the same subject, discussing the final journey to Allah. The writer attempts to present these issues so that the society always remember that the world is a temporary place and the hereafter is the final abode. 
"Pandoga Salah Tingkah" (Iltizam, 2015, p. 161) is a poem that contains a philosophy of life. Pandoga is a Bajau word that represents principles, direction and way of thinking. This poem prompts the reader to be aware that to become a complete human being one must go through various experiences, bitterness, and pain to teach one to become a better human being. "Hoping for rain when you hear thunder, what comes will not even fill the jar" is sarcasm meant to remind the Bajaus not to pin one's hopes on something that is not certain. In this poem, a good reminder and lesson has been delivered by the poet. Allah SWT has also reminded Muslims to work hard to achieve something followed by prayers and then leaving it in God's hands.

The writer is also seen as wanting to be close to Allah SWT as part of his effort to coax others towards the truth and to stay away from falsehood. The poem "Aku, Tuhan dan Hidup" (Iltizam, 2015, p. 109) is a depiction of sad tale of a Sea Bajau child. This poem definitely contains dakwah elements and local wisdom that is garnered from his life journey where he had to face the challenges of living in a city. The poet tries to depict the real situation of these children who are born poor and destitute. The situation is so crippling that they become gum addicts in the alleyways. Looking at the real situation, there are beggars there below the age of twelve. They spend their time begging for sympathy from those who would help especially those who give out money or coins. Nevertheless, the poet slips in some dakwah in the form of a fervent hope that Allah look after their welfare and the lives of these people. Its beauty proves that the poet who lives within the Bajau community is able to interpret the condition of this society.

The fine verses of the poem Aku, Tuhan dan Hidup clealy shows the poet's effort to put forth a different interpretation and picture of the life of the Bajaus some of whom are destitute and outcasts of society. Normally, outsiders have a particular view and perception of the Bajaus, especially the Sea Bajaus. This poem is able to invoke an honest portrayal of a section of the Bajau community who are abandoned and who have to face a bitter life's journey. This portrayal sufficiently provides an interpretation of the conflict of identity and the cynical view of the society towards these children who actually need help and aid to change the lives of their people. Progress and civilization are still far from their reach as the society ignore their existence as a group of people who need help. Allah SWT has urged mankind to fulfil their responsibility towards Him and provide service to those in need. 


\author{
Tuhan \\ bila Kau datang \\ melihat makhlukmu \\ dipacu serupa baghal \\ hilang kendali ini? \\ Tuhan \\ jangan tinggal daku \\ tanpa kendali \\ tali-Mu yang lurus
}

(Iltizam, 2005, p. 110)

[God

when you come

and look at your creatures

ridden like the donkey

that lost its bridle

God

do not leave me

without your bridle

Your straight rope]

The poem's ending is shattering because of the hope expressed by the poet to the Creator of the universe. The poet appeals to the Almighty not to abandon him all alone and expresses the desire to be guided back and move with Allah's help. This poem is able to shake the reader's mind and feelings, interpreting the poets thinking on the philosophy of life.

Zubir (2015), through the poem "Lelaki Sejati" (Real Men) (Iltizam, 2015, p. 188) emphasizes the concept of muruwah, that is, personal pride or honour which is considered a priority for men in the Bajau community. The poet paints a picture of the Bajau men's special qualities, always concerned about ka'ul, pi'il, akkal dan kila-kila or words, action, thinking and balance in everything that they do. This personal pride is a symbol of men's strength other than the adherence to religion and the beauty of life guided by Islamic laws. Islam also emphasises the concept of maruah or morals that should be preserved not only because they are men but also as head of the household and family. This poem clearly emphasizes that which is in accordance with Islamic views that forms the basis of the Bajau society. At a glance, the poem looks simple in arrangement but it embodies a critical and creative line of thinking 
This poem is full of dakwah elements and local wisdom in order to understand the meaning of humanity itself. Due to his love of language, culture and literature, Zubir's poems are beautiful and meaningful. The rendering of his poems leave a great impact and are written in a unique style. The noble and Islamic values are represented in traditional terms that exist in the poet's mind. This particular poem, apart from exploring the personal pride of a man it is also able to put forth the idea that men should be equally self-effacing. The poet does not forget to give examples from the prophets such as Adam, the angels and other important messages in Islam.

The poems, "Tuhan" (God) (Iltizam, 2015, p. 92), "Tidak Menyerah" (Do not surrender) (Iltizam, 2015:125), "Kebesaran Maha Indah" (Greatness is Beautiful (Iltizam, 2015, p. 61), "Mati Sebelum Ajal" (Die before one's Time) (Iltizam, 2015, p. 62) and "Sebutir Debu" (A speck of Dust) (Iltizam, 2015, p. 76) are representative of the writer's awareness of mankind's relationship with God hablum minallah. The use of words such as "Your Greatness, Your Will, divine manifestation, revelation, essence, wisdom" show that these poems are used as a medium for dakwah to the readers. The poet presents a picture of how small and lowly man is and how he should increase his love for Allah. As a man, he will commit errors and this should be followed by forgiveness, repentance and acceptance. The poet is inclined to portray a society that surrenders itself to God in total in the pursuit of heaven. The poems also took Baitullah as the background, and represent it as the purest place of worship for all levels of society including the Bajau community. This background will give the impression that the Bajau community practices a way of life and culture based on true Islamic guidelines.

At a glance, the poems look simple in arrangement but it contains a critical and creative line of thinking. The poems are filled with the element of teaching and becomes a good premise for understanding the meaning of humanity itself. His love for language, culture and literature makes Zubir (2015) poems beautiful and meaningful. His poetic arrangement leaves a strong impact and has a style of its own. The noble Islamic values are represented by traditional terms that exist in the writer's mind. The Bajau society frequently uses nature as the teacher, but they are still the vicegerents of God who continue to worship Allah as the creator of the entire natural world.

On the whole, these poems bring people closer to Allah in all matters. The world is seen as a temporary place where one does as much good deeds as possible to help him in the hereafter. The poet portrays the true man as one who hopes for Allah's forgiveness so that every step he takes is easier 
and blessed. The fires of hell are agonising for those who know. There is an interesting use of the sky and earth metaphor especially because we live between them.

\author{
Aku tenggelam \\ Dalam kebesaran alam \\ Merunduk fikiran \\ Bergetar sukma \\ Hilang ego \\ Sirna kesombongan diri \\ Aku hanya setitis air \\ Dalam lautan tujuh benua \\ [I am drowning \\ In the vastness of the world \\ The mind stoops \\ My heart shakes \\ The ego disappears \\ Self pride vanishes \\ I am just a drop of water \\ In the oceans of seven continents]
}

The poem above, "Alam" (The world) (Iltizam, 2015, p. 32) is a complete surrender of the poet's feelings to God, the Creator of the world. The poet reminds the society that however high we reach, we have to surrender to the power of the Creator. Mankind has been created to worship and be of service to Him. The time of death of all creatures has been determined by Allah and its only to Him that we return. The poet considers himself just a speck of dust when compared to God's greatness.

This poem, when examined comprehensively is able to interpret the Bajau's society's true beliefs represented by the poet. The Sea Bajau society is already in the modern stage compared to what it was previously. They have now begun to know about God and follows the religion that is brought in. They do not only depend on the natural world but are already teaching themselves to learn from their trials and accept life with gratitude and patience. This poem is able to represent the Bajau society's identity that have started to interpret the world and its Creator.

The writer does not forget to put forward the issue of humanity in Gaza Palestine. The agonies and suffering of fellow Muslims in Gaza are interpreted into verses by Zubir (2015). The Bajaus express their sympathy 
and sadness looking at young children being killed, the holy land flooded with blood and tears. Their tears are for the cause of justice and fairness in their own motherland. Their beloved Palestine has a unique history and should be remembered by Muslims all over the world. The poet fights for this in the poems that he writes.

\section{CONCLUSION}

The dakwah and utilitarian approaches which have been employed in this study find that through 59 poems selected from the anthology of poetry, Iltizam by Zubir (2015) it is clear that the elements of dakwah form the main basis in bringing about change to the society today. At the same time, finally these poems portray the real Bajau society. The poet writes beautiful verses to depict the journey of life of his people as well as endeavouring to become a poet that truly follows the principles of Islam, that is to spread the message of doing good and avoiding the bad. The dakwah elements such as invocation, divinity, and Islam are the the main themes in line with local wisdom portrayals that highlight the identity, philosophy, way of life and culture of the writer and the Bajau community. Zubir (2015) endeavours to place himself as a poet who upholds the truth of Islam. The poems that he wrote become a vehicle for dakwah to the public. Zubir's poems clearly leave a strong impact in bringing about awareness to his people so as not to be swayed by the country's development as it can destroy the society's identity and image. The objective of encouraging good and avoiding the bad should become the basis of works with an Islamic bent. Therefore these values should be defended as the symbol of advancement in life of the Bajau community.

\section{REFERENCES}

Asmuni Syukir. (1983). Dasar-dasar strategi dakwah Islam. Surabaya: Penerbit Al-Ikhlas Surabaya.

Hashim Awang. (1989). (Disember, pp. 60-63). Kajian sastera: suatu pendekatan Melayu. Dewan Sastera. Kuala Lumpur: Dewan Bahasa dan Pustaka.

Kamonthip. (2007). Local wisdom, environmental protection and community development: the clam farmers in Tambon Bangkhunsai, Phetchaburi Province, Thailand. MANUSYA: Journal of Humanities, 10(1), 1-10.

Nyoman Utari Vipriyanti. (2008, July). Banjar adat dan local wisdom : community management for public space of sustainability in Bali Province. Paper Presented in IASC 2008 12th Biennial Conference. 
MALAY LITERATURE VOLUME 30 NUMBER 1 JUNE 2017

Othman Haji Talib. 2000. Dakwah dan Pengurusan Islam di Malaysia, konsep dan pelaksanaan. Bangi: Universiti Kebangsaan Malaysia.

Warren, J. F. 1971. The North Borneo Chartered Company's Administration of the Bajau, 1878-1909. Kertas kerja Internasional Studies, Southeast Asia Series, 22, Ohio University Centre For Internasional Studies.

Yap Beng Liang. (1993). Orang Bajau Pulau Omadal, Sabah: aspek-aspek budaya. Kuala Lumpur: Dewan Bahasa dan Pustaka.

Zubir Osman. (2012). Iltizam. Kuala Lumpur: Institut Terjemahan \& Buku Negara Berhad.

Zurinah Hassan. (2008). Puisi Melayu moden: kajian teori pengkaedahan Melayu. (PhD. Thesis). Akademi Pengajian Melayu. Universiti Malaya.

Received: 6 April 2017

Accepted: 2 May 2017 